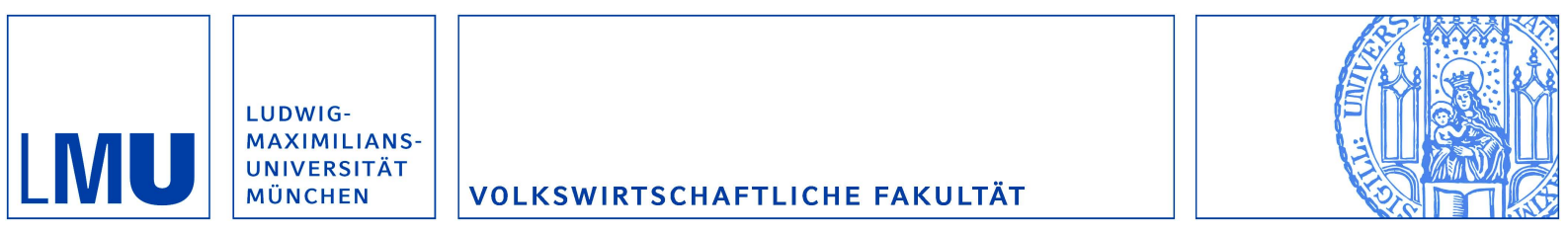

Haufler, Andreas and Klemm, Alexander and Schjelderup, Guttorm:

Globalisation and the mix of wage and profit taxes

Munich Discussion Paper No. 2006-7

Department of Economics

University of Munich

Volkswirtschaftliche Fakultät

Ludwig-Maximilians-Universitäł München

Online at https://doi.org/10.5282/ubm/epub.885 


\title{
Globalisation and the mix of wage and profit taxes*
}

\author{
Andreas Haufler \\ University of Munich \\ Alexander Klemm \\ International Monetary Fund \\ Guttorm Schjelderup \\ Norwegian School of Economics and Business Administration
}

February 2006

\begin{abstract}
This paper analyses the development of the ratio of corporate taxes to wage taxes using a simple political economy model with internationally mobile and immobile firms. Among other results, our model predicts that countries reduce their corporate tax rate, relative to the wage tax, either when preferences for public goods increase or when a rising share of capital is employed in multinational firms. The predicted relationships are tested using panel data for 23 OECD countries for the period 1980 through 2001. The results of the empirical analysis support our central hypotheses.
\end{abstract}

Keywords: Capital and labour taxes, economic integration, multinational firms JEL classifications: H20, H73, F15, F23

*We thank Tony Atkinson, Steve Bond, Lars-Erik Borge, Erik Sørensen, Sven Stöwhase and seminar participants in Bergen and Munich for very useful comments. Schjelderup acknowledges the hospitality of the Center of Economic Studies (CES) at the University of Munich, where this paper was started. The views expressed in this paper are those of the authors and should not be interpreted as the views of the institutions with which they are affiliated. 


\section{Introduction}

There is a widespread concern in public policy that increasing capital market integration is eroding the traditional role of the tax system in equalizing the (after-tax) distribution of income. These concerns are based on the differential development of wage and capital tax rates over the last decades. Data for the member countries of the Organization for Economic Cooperation and Development (OECD) show, for example, that in the early 1980s the statutory tax rate on corporate profits was 50 percent higher, on average, than the labour tax wedge for the average worker. By the year 2000, however, the two tax rates had become roughly equal (see Table 1). Related evidence shows that, on average, European Union (EU) member states have reduced their reliance on capital taxes and increased the share of labour taxes in total tax revenues during the past 30 years (Eurostat 1998, 2005). These developments underlie several current EU policy initiatives, which aim to increase the effective taxation of capital income and, in particular, corporate profits (European Commission 1997, 2001). ${ }^{1}$

In the aggregate, these trends are in line with the results of the tax competition literature, which predict a reduction in the relative reliance on corporate taxes as the optimal response to increased capital market integration (see Wilson, 1999 for a survey). Table 1 also shows, however, that the policy responses to increased capital market integration have been rather diverse, even among the relatively homogeneous group of OECD countries. In some countries (Austria, Finland, Greece and Sweden) the ratio of capital to labour taxes has fallen by more than 50 per cent during the period 1980 through 2001, whereas the same ratio has stayed virtually constant in the United States and it has even increased in Italy, Luxembourg and Spain. Moreover, large differences in the pattern of capital and labour taxation remain. In 2001, for example, the corporate tax rate was only $63 \%$ of the wage tax rate for an average worker in Sweden, but $183 \%$ of the wage tax rate in Japan. Very little theoretical work has been devoted so far to explain these substantial and persistent cross-country differences in the relative reliance on capital and labour taxation. ${ }^{2}$

\footnotetext{
${ }^{1}$ For a detailed survey of the development of corporate taxation in the OECD countries since the 1980s, see Devereux, Griffith, and Klemm (2002).

${ }^{2}$ The only robust link that has been derived in the theoretical tax competition literature is that
} 
Table 1: Taxation of corporate and labour income in the OECD

\begin{tabular}{|l||cc|cc|cc|}
\hline \multicolumn{1}{||||}{} & \multicolumn{2}{|c|}{$\begin{array}{c}\text { statutory } \\
\text { income tax rate }(\tau)^{a}\end{array}$} & \multicolumn{2}{c|}{ tax wedge } & \multicolumn{2}{c|}{ tax ratio } \\
Country & 1980 & 2001 & 1980 & 2001 & 1980 & 2001 \\
\hline Australia & 50.0 & 30.0 & 18.3 & 18.8 & 2.73 & 1.60 \\
Austria & 61.3 & 34.0 & 29.9 & 36.7 & 2.05 & 0.93 \\
Belgium & 48.0 & 40.2 & 41.6 & 47.9 & 1.15 & 0.84 \\
Canada & 44.8 & 35.6 & 18.3 & 25.4 & 2.45 & 1.40 \\
Denmark & 40.0 & 32.0 & 37.0 & 37.1 & 1.08 & 0.86 \\
Finland & 60.2 & 29.0 & 37.4 & 42.4 & 1.61 & 0.68 \\
Germany & 62.2 & 38.3 & 36.1 & 41.8 & 1.72 & 0.92 \\
Greece & 43.4 & 37.5 & 17.4 & 35.8 & 2.49 & 1.05 \\
Ireland & 45.0 & 10.0 & 27.9 & 19.3 & 1.61 & 0.52 \\
Italy & 36.3 & 40.3 & 43.6 & 40.7 & 0.83 & 0.99 \\
Japan & 52.6 & 40.9 & 14.3 & 22.3 & 3.68 & 1.83 \\
Luxembourg & 45.5 & 37.5 & 29.1 & 22.7 & 1.56 & 1.65 \\
Netherlands & 48.0 & 35.0 & 43.8 & 37.6 & 1.10 & 0.93 \\
New Zealand & 45.0 & 33.0 & 20.0 & 18.1 & 2.25 & 1.82 \\
Norway & 50.8 & 28.0 & 37.3 & 31.9 & 1.36 & 0.88 \\
Spain & 33.0 & 35.0 & 34.6 & 34.5 & 0.95 & 1.01 \\
Sweden & 60.4 & 28.0 & 46.7 & 44.8 & 1.29 & 0.63 \\
United Kingdom & 52.0 & 30.0 & 31.4 & 23.9 & 1.66 & 1.26 \\
United States & 49.6 & 39.3 & 29.4 & 24.0 & 1.69 & 1.64 \\
\hline \hline OECD average & 48.8 & 33.3 & 31.3 & 31.9 & 1.75 & 1.13 \\
\hline coeff. of variation & 0.16 & 0.21 & 0.31 & 0.29 & 0.40 & 0.35 \\
\hline
\end{tabular}

Sources: Corporate taxes: IFS tax data (www.ifs.org.uk/publications.php?publication_id=3210); own calculations. Labour tax wedge: OECD, Taxing wages (new.sourceoecd.org).

${ }^{a}$ Including typical local income taxes and supplementary charges. In countries with more than one tax rate, the manufacturing rate was chosen.

${ }^{b}$ Average tax rate faced by a manufacturing employee on average income. Includes personal income taxes, social security contributions and payroll taxes. 
Against this background, the present focuses on the effects that country-specific variables have on the mix of wage and profit taxation under conditions of capital market integration. A distinguishing feature of our paper is that all hypotheses are derived from a simple, yet fully specified model and are then taken directly to the empirical tests. Our theoretical analysis draws on the traditional model of capital tax competition, but it also incorporates some of the recent developments related to the taxation of multinational firms. ${ }^{3}$ We introduce a simple political-economy model with two types of voters, workers and capitalists. Workers can avoid taxation by working in the shadow economy, whereas capital owners of multinational (but not domestic) firms can escape high taxes by moving activities abroad. The model is simple enough to derive reduced-form expressions for the optimal wage and profit taxes in the political-economic equilibrium, ensuring sharp comparative static effects. Our theoretical model incorporates several of the core findings of the capital tax competition literature. In addition, it predicts that countries reduce their corporate tax rates, relative to the wage tax, either when preferences for public goods increase or when a rising share of capital is employed in multinational firms.

In a second step, we test the predicted relationships using a panel data set from 23 OECD countries for the period 1980 through 2001. The empirical analysis supports our central theoretical results. In particular, the share of government consumption (excluding transfers and social security contributions) is found to have a robust negative effect on the ratio of corporate taxation to wage taxation. Moreover, we proxy the share of multinational firms in an economy by the value added in the manufacturing sector, relative to the value added in the service sector. This measure for the potential mobility of the corporate tax base is also found to have a negative and significant impact on the ratio of corporate taxation to wage taxation.

Our empirical analysis relates to several recent studies which regress the mix of profit and wage taxation on various measures of capital market integration (Rodrik 1997; Bretschger and Hettich 2002; Slemrod 2004; Winner 2005). ${ }^{4}$ Like these studies, our small countries will face a higher elasticity of the capital tax base and will therefore, on average, have a smaller capital tax rate than their larger neighbours. See Bucovetsky (1991) and Wilson (1991).

${ }^{3}$ Examples are Mintz and Smart (2004) and Kind et al. (2005). For an empirical account of the rise in FDI and multinational firm activity over the last two decades, see Markusen (2002, ch. 1).

${ }^{4} \mathrm{~A}$ different, and complementary, strand in the recent empirical literature tests for the presence of 
results support the general prediction of the tax competition literature that increased capital market integration tends to shift the burden of factor taxation from mobile capital to less mobile labour. ${ }^{5}$ Our results go beyond these earlier studies, however, by relating the mix of factor taxation to a number of country-specific variables derived from our theoretical model. Specifically, the share of multinational firms (proxied by the sectoral composition of output) can be interpreted as a country-specific measure of the exposure to capital market integration, whereas the share of public consumption expenditures points to the importance of domestic factors in explaining the observed tax mix. We argue that these results offer some explanation for the persistence of crosscountry differences in the ratio of capital taxation to wage taxation under conditions where the integration of OECD countries into world capital markets is almost complete. Section 2 of this paper develops the model and derives its comparative static effects. These serve as theoretical hypotheses for the ensuing empirical analysis, which is described in Section 3. Section 4 compares our results with those obtained in related work. Section 5 concludes.

\section{A simple model of the optimal direct tax mix}

\subsection{The framework}

We consider a small open economy with two groups of consumers, capitalists and workers. Capitalists receive only capital income, whereas workers receive only wage income. The total population is normalised to unity, and is divided between $\mu$ workers and $(1-\mu)$ capitalists. We assume $\mu>0.5$, i.e. workers are in the majority and will

strategic interaction between tax-setting governments. See, for example, Besley et al. (2001), Devereux et al. (2002), or Brueckner (2003) for an overview.

${ }^{5}$ This contradicts earlier studies in the political science literature, which found that higher capital mobility is associated with higher revenues derived from capital taxation. That literature argued that the effects of capital tax competition are more than offset by an increased demand for government redistribution, in order to insulate individuals from globalisation-related risks (the so-called 'compensation hypothesis'). More recent work in the political science literature has, however, confirmed the negative effect of capital market integration on the rate of capital taxation. See Swank and Steinmo (2002) and the references cited there. 
determine the political-economic equilibrium in our model. Capitalists receive income from two representative firms, one domestic and one multinational. The capital stocks in the domestic and the multinational firm are $k^{D}$ and $k^{M}$, respectively, where the total capital endowment is denoted by $K \equiv k^{D}+k^{M}$. Capital cannot be shifted between the domestic and the international firm. ${ }^{6}$

The representative capitalist in the small country faces an exogenous world interest rate, normalised to one. Capital income in the home country is taxed by a proportional corporation tax levied at rate $\tau$. The multinational firm, but not the domestic firm, can relocate part of its capital to a foreign country for tax reasons, where it is taxed at the exogenously given 'world' tax rate $\bar{\tau}<\tau$. Hence, the domestic country is a hightax country relative to the rest of the world. ${ }^{7}$ We assume here that the relocation of capital has real effects, reducing the capital stock in the home country. ${ }^{8}$ In doing so, the multinational firm incurs costs that are a convex (for simplicity, quadratic) function of the share of relocated capital. Denoting the share of capital in the multinational firm that is moved abroad by $\beta^{C}$, the relocation costs are $F^{C}=\alpha^{C} k^{M}\left(\beta^{C}\right)^{2} / 2$, where $\alpha^{C}$ is a net of tax cost parameter. The after-tax income of the capitalist is then

$$
I^{C}=\left[k^{D}+\left(1-\beta^{C}\right) k^{M}\right](1-\tau)+\beta^{C} k^{M}(1-\bar{\tau})-\frac{\alpha^{C} k^{M}\left(\beta^{C}\right)^{2}}{2},
$$

where the first two terms are the after-tax incomes in the home and the foreign country, respectively, and the last term gives the (net-of-tax) cost of relocating operations.

The owners of multinational firms choose the share $\beta^{C}$ of their foreign operations. Maximisation of (1) with respect to $\beta^{C}$ yields $\beta^{C}=(\tau-\bar{\tau}) / \alpha^{C}$. Incorporating this profit-maximising behaviour and introducing $k^{M}=s K$ to describe the multinational

\footnotetext{
${ }^{6}$ This assumption, which is made in most of the existing public finance literature, implies that the firms' choice between a national and a multinational form is not systematically affected by taxes. For a recent analysis in which firms change their organizational structures in response to long-term tax incentives, see Bucovetsky and Haufler (2005).

${ }^{7}$ Alternatively, the 'world tax rate' can be interpreted as the rate offered internationally by low-tax countries.

${ }^{8} \mathrm{An}$ alternative interpretation is that multinational firms can shelter profit income from domestic tax by thin capitalization, borrowing money as necessary from an affiliate in a tax haven (Mintz and Smart, 2004).
} 
sector's share of the total capital stock, the domestic capital stock is

$$
\kappa=k^{D}+\left(1-\beta^{C}\right) k^{M}=K\left[1-\frac{s(\tau-\bar{\tau})^{2}}{\alpha^{C}}\right] .
$$

Turning to workers, their gross wage depends on the amount of capital operating in the home country. Specifically, let the gross wage be a linear function of capital employed domestically (by national and by multinational firms), and denote by $0<\rho<1$ the proportionality factor with which this capital stock affects the gross wage. Hence

$$
\omega=\rho \kappa=\rho K\left[1-\frac{s(\tau-\bar{\tau})^{2}}{\alpha^{C}}\right] .
$$

The dependence of the wage rate on the domestic capital stock gives the voting majority of workers an incentive to choose a mix of wage and profit taxes, rather than rely exclusively on profit taxation.

The second tax in the model is a linear tax on wages, levied at rate $t$. Workers can avoid the wage tax by working in the shadow economy, but this is associated with a deadweight cost. We formulate the tax avoidance decision of workers in an analogous way as that for multinational firms and denote by $\beta^{W}$ the share of work income relocated to the shadow economy. The deadweight cost of this operation is $F^{W}=\alpha^{W} \omega\left(\beta^{W}\right)^{2} / 2$. The net income of a representative worker is then, using (3)

$$
I^{W}=\rho K\left[1-\frac{s(\tau-\bar{\tau})}{\alpha^{C}}\right]\left[1-t\left(1-\beta^{W}\right)-\frac{\alpha^{W}\left(\beta^{W}\right)^{2}}{2}\right] .
$$

Maximisation with respect to $\beta^{W}$ gives $\beta^{W}=t / \alpha^{W}$. Substituting into (4) yields the maximised after-tax income of each worker as

$$
I^{W *}=\rho K\left[1-\frac{s(\tau-\bar{\tau})}{\alpha^{C}}\right]\left[1-t\left(1-\frac{t}{2 \alpha^{W}}\right)\right] .
$$

The share of capital income earned domestically forms the base of the corporation tax, whereas the labour tax falls on all wage income that is legally earned. Recalling that there are $\mu$ workers and $1-\mu$ capitalists in the economy, total tax revenue (which equals per-capita tax revenue, since the population is normalised to unity) is given by

$$
T=K\left[1-\frac{s(\tau-\bar{\tau})}{\alpha^{C}}\right]\left[t \mu \rho\left(1-\frac{t}{\alpha^{W}}\right)+\tau(1-\mu)\right] .
$$

A representative worker derives utility from her maximised after-tax income $I^{W *}$ and a quasi-private public good. The assumption that there are no economies of scale in the 
provision of the public good makes the results of the analysis comparable for countries of different size, as will be further discussed below. Both the private and the public good enter the worker's utility function linearly and the marginal benefit of the public good is assumed to be constant, and denoted by $\gamma \cdot{ }^{9}$ With these specifications, the utility of a representative worker is $U^{W}=I^{*}+\gamma T$, which by use of (5) and (6) can be written as

$U^{W}=K\left(1-\frac{s(\tau-\bar{\tau})}{\alpha^{C}}\right)\left\{\rho\left[1-t\left(1-\frac{t}{2 \alpha^{W}}\right)\right]+\gamma\left[t \mu \rho\left(1-\frac{t}{\alpha^{W}}\right)+\tau(1-\mu)\right]\right\}$.

Given that the median voter in our economy is a worker, the equilibrium policy maximises $U^{W}$ with respect to the two tax instruments $\tau$ and $t$. In a first step the optimal wage tax is derived as

$$
t^{*}=\frac{\alpha^{W}(\gamma \mu-1)}{(2 \gamma \mu-1)}
$$

The equilibrium wage tax is thus linearly rising in the cost parameter $\alpha^{W}$. The wage tax will be positive, if the marginal benefit from this tax, $\gamma \mu$ (the value of one unit of the public good, multiplied by the share of workers on whom the tax is imposed), exceeds the marginal cost (which equals one). In the following we assume that this condition is met and $t^{*}>0$ in the optimum.

In a second step the optimal corporation tax rate is derived using (7). This yields

$$
\tau^{*}=\frac{\alpha^{C}}{2 s}+\frac{\bar{\tau}}{2}-\frac{\rho}{2 \gamma(1-\mu)}\left[1+\frac{\alpha^{W}(\gamma \mu-1)^{2}}{2(2 \gamma \mu-1)}\right] .
$$

The corporate tax rate consists of two parts. The first, positive part describes the benefits, from the perspective of workers, of taxing capital income. This effect will be large when the share of the mobile, multinational tax base $s$ is low, or when it is unattractive for multinationals to shift capital abroad, due to either high foreign taxes $\bar{\tau}$ or a high cost parameter $\alpha^{C}$. The second, negative part describes the incentive for

\footnotetext{
${ }^{9}$ Note that interior solutions for optimal tax rates are obtained in our model, despite the linearity of the objective function in both private income and public goods. This is because the excess burden of taxation is strictly convex in each of the two tax rates. In principle, $\gamma$ could be allowed to vary, displaying decreasing marginal utility. This would not alter the fundamental insights that follow from the analysis, but would complicate the model substantially.
} 
workers to subsidise domestic capital, in order to raise gross wages. ${ }^{10}$ This incentive is rising in $\rho$. The capital tax will be positive if, in the valuation of workers, the revenue gains from the taxation of capital income exceed the induced reduction in gross wages. This is assumed in what follows.

\subsection{Determinants of the equilibrium tax mix}

In this section we derive the comparative static effects of changes in the exogenous parameters on the mix of wage and capital taxes that the working majority chooses in equilibrium. In doing so we incorporate a number of basic insights from the theoretical literature on taxation in open economies, but we also derive some new results. Throughout, we assume that both tax rates are strictly positive in equilibrium.

A first and straightforward exercise is to determine the effects of an increase in the foreign (world) tax rate $\bar{\tau}$. From (7) and (8) this unambiguously increases the relative reliance on the corporation tax

$$
\frac{\partial(\tau / t)}{\partial \bar{\tau}}=\frac{1}{2 t}>0
$$

This simple comparative static effect corresponds to upward-sloping best response functions in more complex models of interdependent tax-setting by regional governments. The latter result underlies virtually all of the literature on capital tax competition (cf. Wilson, 1999).

Next, we consider the effects of market integration. An increase in the relocation cost parameter $\alpha^{C}$ changes the equilibrium tax mix by.

$$
\frac{\partial(\tau / t)}{\partial \alpha^{C}}=\frac{1}{2 s t}>0
$$

In our model increased capital market integration is given by a fall in the relocation cost parameter $\alpha^{C}$. As seen from (10), the effects of lower shifting costs make the aggregate capital tax base more elastic and reduce the equilibrium tax on this base. Since the wage tax is not affected, economic integration also reduces the relative reliance on

\footnotetext{
${ }^{10}$ Similar effects are present in more complex models of wage determination. Fuest and Huber (2000), for example, show in a wage bargaining model that investment subsidies are preferred to direct employment subsidies, because they reduce the bargaining position of trade unions.
} 
profit taxes. Again, this is one of the effects that are frequently analysed in the tax competition literature (e.g. Persson and Tabellini, 1992; Kind et al., 2005). ${ }^{11}$

Changes in either the world (average) tax rate or the degree of capital market integration will affect all countries in similar ways. The latter holds at least for the OECD countries, which have lifted all remaining capital controls in the early 1990s and where further capital market integration reflects general improvements in information technologies. Our model shows, however, that changing the country-specific share of capital in the multinational sector gives similar predictions as increased capital market integration. Raising $s$ while holding the total capital stock constant yields

$$
\frac{\partial(\tau / t)}{\partial s}=\frac{-\alpha^{C}}{s^{2} t}<0
$$

A higher proportion of internationally mobile capital raises the average elasticity of the corporate tax base, even when $\alpha^{C}$ is held constant. In equilibrium this lowers the tax rate on capital, relative to the wage tax.

A well-known result is that small countries levy lower capital tax rates than their larger neighbours (Bucovetsky, 1991; Wilson, 1991). This result also extends to settings where countries tax profits from FDI (Haufler and Wooton, 1999). We can relate our result in eq. (11) above to this literature, if we assume that the share of the multinational sector is larger in small countries. One reason for this could be that the motive to engage in horizontal (market-seeking) FDI becomes more important when the firm's home market is small. We will examine this relationship in our empirical analysis below.

A further important determinant are the median voter's preferences for public goods, as captured by the parameter $\gamma$. This parameter affects the two taxes in our model by

$$
\frac{\partial \tau}{\partial \gamma}=\frac{\rho\left[2(2 \gamma \mu-1)^{2}-\alpha^{W}(\gamma \mu-1)(3 \gamma \mu-1)\right]}{4 \gamma^{2}(1-\mu)(2 \gamma \mu-1)^{2} t} ; \quad \frac{\partial t}{\partial \gamma}=\frac{\alpha^{W} \mu}{(2 \gamma \mu-1)^{2}}>0 .
$$

A stronger preference for the public good will unambiguously raise the wage tax $t$, but the same need not be true for the corporation tax. The reason for the latter result is that an increase in $\tau$ will raise revenues from the corporation tax but, through the negative effect on wages, simultaneously reduces labour tax revenues. If the cost of working in

\footnotetext{
${ }^{11}$ Similar effects arise in models of capital and wage taxation when capital is internationally mobile and the number of countries competing for capital is increased (Bucovetsky and Wilson, 1991).
} 
the shadow economy for the worker $\left(\alpha^{W}\right)$ is sufficiently large, implying - realistically - that most of tax revenues is raised from wage taxes, the negative repercussions of a capital tax increase on wage tax collections will be strong. Intuitively, in this case the excess burden associated with corporate taxation rises more steeply than the excess burden of wage taxation. Hence a higher tax revenue requirement will be predominantly met by higher wage taxes, whereas the corporation tax remains largely unaffected or may even be reduced.

Finally, we consider the effect of changing the share of workers $\mu$. This affects taxes by

$$
\begin{aligned}
\frac{\partial \tau}{\partial \mu} & =\frac{-\rho\left\{2(2 \gamma \mu-1)^{2}+\alpha^{W}(\gamma \mu-1)\left[(\gamma \mu-1)(2 \gamma \mu-1)+2 \gamma^{2}(1-\mu) \mu\right]\right\}}{4 \gamma(1-\mu)^{2}(2 \gamma \mu-1)^{2}}<0 \\
\frac{\partial t}{\partial \mu} & =\frac{\alpha^{W} \gamma}{(2 \gamma \mu-1)^{2}}>0 .
\end{aligned}
$$

Hence our model has the somewhat surprising implication that an increase in the share of workers will unambiguously increase the reliance on the wage tax, relative to the corporation tax. This effect is driven by changes in the size of tax bases: a rise in $\mu$ increases the base of the wage tax while decreasing the base of the corporation tax. Changing the number of workers and capitalists has no further repercussions on the factor tax mix chosen in the political-economic equilibrium, due to our assumption that the political power is exclusively in the hands of workers.

The comparative static results from our theoretical model are summarised in

Proposition 1: The following changes in exogenous parameters reduce the rate of the corporation tax, relative to the rate of wage taxation:

(a) a lower world average tax rate $(\bar{\tau})$;

(b) a fall in the costs of moving corporate activities abroad $\left(\alpha^{C}\right)$;

(c) a higher share of capital income earned by multinational firms (s);

(d) an increase in the preference for public goods $(\gamma)$, if the costs of shifting domestic income to the shadow economy is sufficiently high;

(e) a rise in the share of wage income $(\mu)$. 


\section{Empirical results}

The stylised model described above has allowed us to derive rigorously a number of comparative static effects, which represent theoretical hypotheses on country-specific determinants for the optimal mix of wage and profit taxation. In this section we discuss how these predictions can be tested with available data and present our results.

\subsection{Data}

The data requirements for our analysis, which tests a relatively wide range of predictions, are substantial. Therefore we focus on a panel of 23 OECD countries, for which the relevant data can be obtained. Our analysis covers the time period from 1980 to 2001. This period was characterised by the removal of the remaining capital market controls among the developed countries, and by a rapid growth of foreign direct investment (see Markusen, 2002, ch. 1).

\subsubsection{Tax measures}

In constructing the data set for the empirical analysis, a first and important choice that needs to be made is how to measure tax rates. For convenience, implicit tax rates are often computed, where tax revenues from a given source are divided by the corresponding tax base obtained from national accounts statistics. The advantage of that approach is that such data are widely available, and that they include the effects of all aspects of complicated tax systems. For corporate income however, they also have important drawbacks. As documented in Devereux and Klemm (2004), the movement over time of revenue-based tax measures can have little in common with changes in tax laws. Instead they are mainly driven by the business cycle, historical effects, such as accumulated losses, and many other factors that are impossible to control for econometrically. They are therefore not likely to be useful in the context of a model that attempts to explain tax setting behaviour, rather than predict tax revenues. ${ }^{12}$

\footnotetext{
${ }^{12}$ This expectation is confirmed by the empirical results of Slemrod (2004), who tests alternative specifications using either statutory corporate tax rates or a corporate tax measure based on collected revenue. Slemrod's regressions for the revenue-based measure mostly yield coefficients that are
} 
In order to model corporate income tax rates, we therefore use measures exclusively based on tax laws. In particular, we use the statutory tax rate, carefully adding any sub-federal taxes or averages thereof as well as any supplementary charges. While this measure does not include the effect of tax laws on the tax base, such as the value of investment allowances, it is still a core determinant of investment decisions. ${ }^{13}$

A symmetric treatment of wage taxes would imply using the top marginal income tax rate, adding in the rate of social security contributions and, where applicable, payroll taxes. This approach has, however, one important disadvantage: in the early 1980s top rates were extremely high in a number of countries. As the threshold for such rates was also high, they were irrelevant for the majority of the population, except a few high income earners. They are therefore not useful for testing a model in which the median voter determines the policy outcome. What is needed instead is a typical tax rate faced by an average worker, as provided by the OECD (2005). This measure gives the tax rate faced by a manufacturing worker on the mean salary, and includes social security and payroll taxes.

\subsubsection{Explanatory variables}

Turning to the explanatory variables, we proxy the preference for public goods $(\gamma)$ by government consumption expenditure as a share of GDP. ${ }^{14}$ For the share of workers in the economy $(\mu)$ we use wages and salaries divided by GDP. This measure is used because it is likely to proxy not only for the quantity of workers, but also for their quality. For the world tax rate $(\bar{\tau})$, we use the unweighted average of corporate tax rates in a sample of 70 countries. Details on the precise definition and the source of insignificant, or of unexpected sign. Cf. also footnote 5 .

${ }^{13}$ One of the most commonly used tax measures is the (microeconomic) effective average tax rate, developed by Devereux and Griffith (2003). This measure is equivalent to a weighted average of the effective marginal tax rate on an investment that just earns a net rate of return equal to the going interest rate, and the statutory tax rate. The weight of the statutory tax rate in this measure rises with the profitability of the underlying investment project.

${ }^{14}$ Note that this measure does not include transfers, such as most social security expenditure. If the latter were included, a positive relationship between public expenditure and labour taxes would be implicit in our data, as social security contributions are often tied to expenditure by social security funds. 
these data are given in the appendix (Table A.1).

A core variable in previous empirical studies has been the cost of international capital relocation $\left(\alpha^{C}\right)$, or the 'openness' of the economy. A traditional measure for this variable is the share of imports and exports in GDP (see, e.g. Rodrik, 1997). Note, however, that using this proxy in an analysis of the determinants of factor taxes implicitly assumes that trade flows and capital flows are complements. For this assumption no (unambiguous) theoretical foundation exists in trade theory. An alternative measure is a qualitative index of capital market restrictions, as developed in Quinn (1997) and used, for example, in the analyses of Bretschger and Hettich (2002) and Swank and Steinmo (2002). For the OECD countries in our sample this measure exhibits, however, little variation during the last 10 years, as capital markets have been almost completely liberalised throughout this period. Despite their shortcomings, we consider both variables as regressors in the empirical analysis.

Importantly, previous studies have been based on measures of 'openness' that relate to the overall mobility of (portfolio) capital. ${ }^{15}$ When, as in our analysis, the focus lies on the taxation of corporate profits, it is preferable to use a measure of openness that is directly related to foreign direct investment. Our theoretical analysis has suggested that a rise in the share of the multinational capital stock $(s)$ will have similar effects as a fall in the relocation costs of capital. It is however difficult to obtain a measure of the capital stock owned by multinational firms, as this would need to include their entire capital stock, and not just the portion relocated abroad. Nevertheless, it appears likely that the stock of foreign direct investment is related to the capital stock of multinationals, and can therefore be used as a proxy. However, as our theoretical analysis has shown, the size of outward FDI is determined by the share of capital in multinational firms $\left(s K=k^{M}\right)$, multiplied by the share of capital that is moved abroad $\left(\beta^{C}\right)$. Since this share is in turn positively related to the corporate tax rate, the relationship between the domestic tax rate and the size of foreign direct investment is ambiguous a priori. Moreover, the fact that FDI is an endogenous variable in our analysis needs to be allowed for econometrically.

To overcome these difficulties, we employ the industrial structure of the economy as a

\footnotetext{
${ }^{15}$ This also applies to the study by Winner (2005) where capital market openness is proxied by a low savings-investment correlation.
} 
proxy for the share of the multinational sector. Specifically, we use the ratio of value added in the service sector to value added in manufacturing as an indicator for a low share of multinationals in the economy. The use of this proxy is based on statistics collected by the OECD (2001) for a subsample of the countries covered in our analysis. These data show, for both inward and outward FDI, that in most countries the turnover of multinational firms as a share of total sectoral output is substantially larger in manufacturing than in the service sector (see Table A.2 in the appendix). There are two main reasons why this link between the sectoral composition of output and the share of multinational firms can be expected. First, a substantial part of the tertiary sector are locally provided services, including retail trade, transport and storage and community social services, which do not lend themselves to a multinational organizational form. Secondly, multinational firms are known to be particularly important in sectors characterised by high levels of $R \& D$ and high levels of product differentiation (Markusen 2002, ch. 1). While these characteristics also apply to certain parts of the service sector, they are more widespread, on average, in manufacturing. ${ }^{16}$

Finally, we include the level of GDP (measured in purchasing power parities) as a measure of country size. This follows the results in the theoretical literature on capital tax competition that smaller countries tend face a higher elasticity of the capital tax base, other things being equal, and will thus have a lower ratio of corporate to wage taxes in equilibrium. ${ }^{17}$ Table 2 summarises how the predictions from our theoretical model are tested empirically. Some descriptive statistics are provided in Table 3.

\footnotetext{
${ }^{16} \mathrm{~A}$ potential disadvantage of our measure is that the sectoral composition of output may change over the economic cycle. There seems to be no literature addressing this question directly, but related studies suggest that this effect is not very pronounced. Jimeno (1992) argues that sectoral shocks have only limited aggregate effects. As he considers sectors at a more disaggregated level, this is consistent with assuming no major changes in the relationship between service and manufacturing sectors. Similarly, Ghosh and Wolf (1997) argue that geographical shocks are more important than sectoral shocks in explaining the US aggregate economic climate. In any event, time fixed effects will allow for any common cyclical effects in our regression analysis.

${ }^{17}$ The empirical link between country size and the level of corporation tax is stressed by several authors. See, for example, Grubert and Mutti (2000) and Sørensen (2000).
} 
Table 2: Empirical implementation of the model

\begin{tabular}{|c|c|c|c|}
\hline $\begin{array}{c}\text { parameter in } \\
\text { theoretical } \\
\text { model }\end{array}$ & $\begin{array}{c}\text { label in } \\
\text { regression } \\
\text { analysis }\end{array}$ & $\begin{array}{c}\text { predicted } \\
\text { sign on } \\
\tau / t\end{array}$ & description \\
\hline \hline $\bar{\tau}$ & world_tax & $(+)$ & average corporation tax in world sample \\
\hline$\gamma$ & pub_cons & $(-)$ & government consumption / GDP \\
\hline$\mu$ & wage_share & $(-)$ & wages + salaries / GDP \\
\hline \multirow{2}{*}{$\alpha^{c}$} & trade_share & $(-)$ & (imports + exports) / GDP \\
\cline { 2 - 4 } & cap_controls & $(-)^{a}$ & index of capital control measures \\
\hline$s$ & service_share & $(+)$ & value added in services/manufacturing \\
\cline { 2 - 4 } & GDP & $(+)$ & level of domestic product \\
\hline$\beta^{C} \times s$ & FDI_stock & $(+,-)$ & outward FDI stock/GDP \\
\hline
\end{tabular}

${ }^{a}$ A low value of the index indicates strict capital controls (cf. Table A.1).

Table 3: Descriptive statistics

\begin{tabular}{|c|c|c|c|c|c|c|}
\hline variable & $\begin{array}{c}\text { obser- } \\
\text { vations }\end{array}$ & mean & median & $\begin{array}{c}\text { standard } \\
\text { deviation }\end{array}$ & min. & max. \\
\hline \hline tax ratio & 418 & 1.347 & 1.236 & .612 & .272 & 3.745 \\
\hline world_tax & 418 & .358 & .353 & .039 & .301 & .411 \\
\hline pub_cons & 418 & .199 & .195 & .037 & .129 & .272 \\
\hline wage_share & 392 & .442 & .450 & .055 & .248 & .555 \\
\hline trade_share & 242 & .159 & .107 & .143 & .007 & .852 \\
\hline cap_controls & 318 & 3.431 & 3.5 & .609 & 2 & 4 \\
\hline service_share & 387 & 3.506 & 3.386 & .999 & 1.886 & 7.970 \\
\hline GDP & 418 & .753 & .193 & 1.479 & .004 & 10.049 \\
\hline FDI_stock & 418 & .725 & .592 & .468 & .160 & 2.895 \\
\hline
\end{tabular}

See definitions in Table A.1. 
Figure 1: Average corporate income tax rate and wage tax rate over time

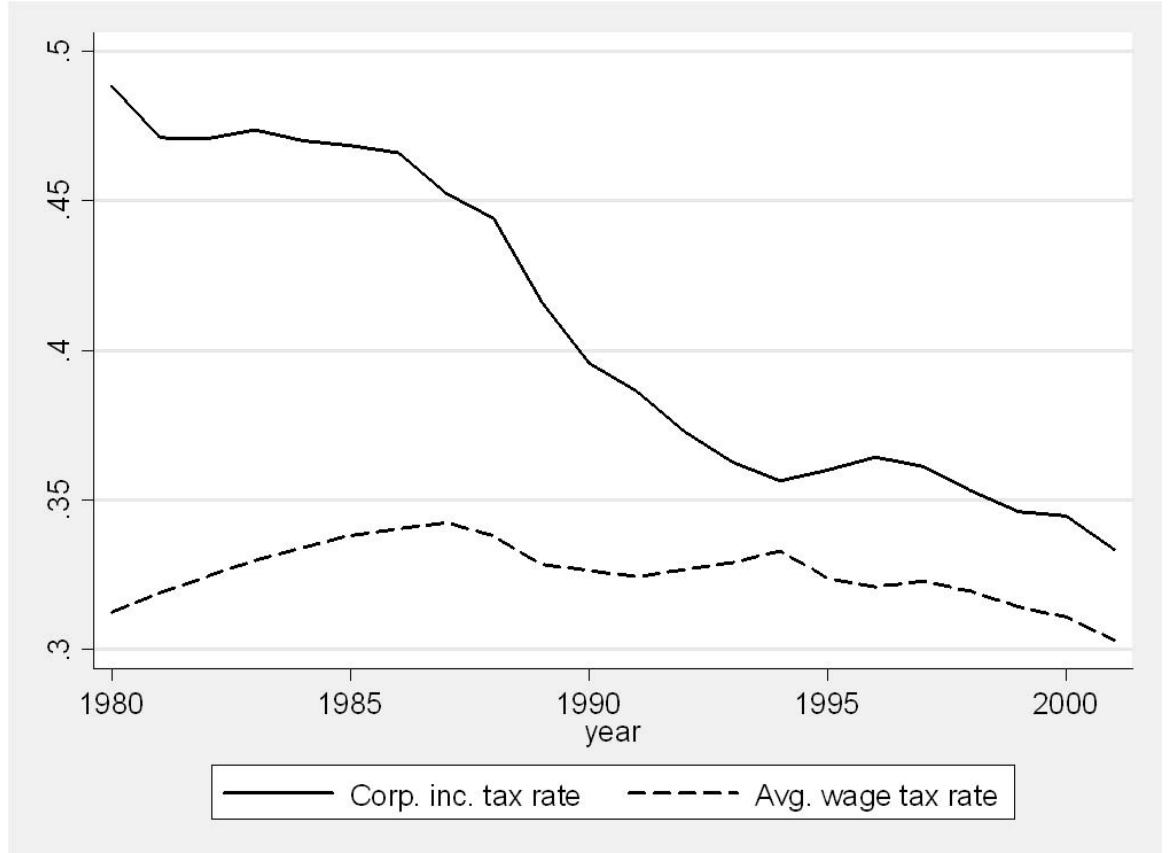

Note: The average was calculated on those 19 countries, for which uninterrupted data are available from 1980-2001.

\subsection{Results}

To summarise the facts to be explained, Figure 1 plots both the statutory corporate income tax rate and the wage tax for the average worker (as discussed in 3.1.1 above) over time. ${ }^{18}$ The figure shows that corporate income taxes have fallen substantially since 1980, particularly in the late 1980s and early 1990s. Average wage taxes on the other hand have been changing without a clear trend and within a relatively narrow range of 30 to 35 per cent.

To reveal the relationship between the ratio of corporate to labour taxes and the exogenous parameters described above, we use standard panel data methods. Specifically we run (OLS) regressions of the form

$$
(\tau / t)_{i t}=X_{i t} \beta+\eta_{i}+\zeta_{t}+\varepsilon_{i t}
$$

\footnotetext{
${ }^{18} \mathrm{~A}$ matrix of charts displaying the development of the ratios of corporate to wage tax rates in the individual countries covered by our analysis is found in the appendix (Figure A.1).
} 
where $(\tau / t)_{i t}$ is the tax ratio in country $i$ at time $t, X_{i t}$ are explanatory variables, $\eta_{i}$ and $\zeta_{t}$ are fixed country and time effects and $\varepsilon_{i t}$ is a possibly heteroskedastic error.

An important feature of our empirical analysis is that we incorporate country fixed effects in all regressions (except for one sensitivity test). This procedure follows from a rigorous interpretation of our theoretical comparative static results: they derive hypothesis on how the tax mix adjusts within a given country when one of the exogenous variables changes. A cross-country interpretation of these effects would thus be permitted only, if our model incorporated all variables that explain differences in the tax mix between countries. Clearly, this cannot be claimed for our simple model. The same point can also be stated econometrically. Since it is likely that we have omitted important variables, a regression that does not use fixed country effects will yield biased estimates, if the omitted variables are correlated in some way with the variables that are included in our regression. These expectations are confirmed by standard Hausman tests, which suggest that fixed country effects should be used consistently in our analysis. The estimates derived from our specification with country fixed effects will then be unbiased, if the unobserved variables do not change over time.

The results from our main set of regressions are summarised in Table 4. In these regressions we have also included time fixed effects. Note, however, that using time effects does not permit us to incorporate the world average tax rate. As this is the same for all countries, it would be perfectly collinear with time effects, and estimation would not be possible. The world average tax rate is therefore included in a second set of regressions, to be presented below.

Column (1) of Table 4 relates the endogenous variable to parameters of the domestic economy only. The coefficient of the public consumption variable is significant and has the expected negative sign. Moreover this relationship is a robust one, as the further regressions show. This provides evidence that an increase in government consumption changes the tax mix in the direction of a higher share of wage taxation, as predicted in Proposition 1(d). The relationship is important also in size, as a coefficient of about 4 implies that an increase in the government consumption share of GDP by one percentage point will reduce the ratio of tax rates by 4 percentage points. Recall also that transfers and social security expenditures are not included in our measure of public consumption (cf. footnote 14); hence the relationship found in our regression analysis is 
Table 4: Estimation results - Baseline case

\begin{tabular}{|c|c|c|c|c|c|c|}
\hline \multirow[b]{2}{*}{ dependent variable } & $(1)$ & $(2)$ & $(3)$ & $(4)$ & $(5)$ & $(6)$ \\
\hline & \multicolumn{6}{|c|}{ corporate income tax / wage tax $(\tau / t)$} \\
\hline country effects & $\sqrt{ }$ & $\sqrt{ }$ & $\sqrt{ }$ & - & $\sqrt{ }$ & $\sqrt{ }$ \\
\hline year effects & $\sqrt{ }$ & $\sqrt{ }$ & $\sqrt{ }$ & $\sqrt{ }$ & $\sqrt{ }$ & $\sqrt{ }$ \\
\hline IV & - & - & - & - & $\sqrt{ }$ & - \\
\hline pub_cons & $\begin{array}{l}-3.900^{* *} \\
(1.552)\end{array}$ & $\begin{array}{l}-3.565^{* *} \\
(1.507)\end{array}$ & $\begin{array}{l}-6.590^{* * *} \\
(1.598)\end{array}$ & $\begin{array}{l}-7.639^{* * *} \\
(1.157)\end{array}$ & $\begin{array}{c}-12.134 \\
(7.580)\end{array}$ & $\begin{array}{l}-4.200^{* * *} \\
(1.499)\end{array}$ \\
\hline wage_share & $\begin{array}{l}0.205 \\
(0.906)\end{array}$ & $\begin{array}{l}0.509 \\
(0.960)\end{array}$ & $\begin{array}{l}1.618 \\
(0.991)\end{array}$ & $\begin{array}{l}3.833^{* * *} \\
(0.574)\end{array}$ & $\begin{array}{l}0.080 \\
(1.909)\end{array}$ & $\begin{array}{l}0.504 \\
(0.751)\end{array}$ \\
\hline GDP & $\begin{array}{l}0.028 \\
(0.021)\end{array}$ & $\begin{array}{l}0.032 \\
(0.020)\end{array}$ & $\begin{array}{l}0.052^{* * *} \\
(0.018)\end{array}$ & $\begin{array}{l}-0.032 \\
(0.026)\end{array}$ & $\begin{array}{c}-0.123 \\
(0.220)\end{array}$ & $\begin{array}{l}0.025 \\
(0.020)\end{array}$ \\
\hline trade_share & & $\begin{array}{l}0.176 \\
(0.147)\end{array}$ & & & & \\
\hline cap_controls & & & $\begin{array}{l}0.109^{* * *} \\
(0.039)\end{array}$ & $\begin{array}{l}-0.290^{* * *} \\
(0.063)\end{array}$ & & \\
\hline FDI_stock & & & & & $\begin{array}{l}-4.694 \\
(5.358)\end{array}$ & \\
\hline service_share & & & & & & $\begin{array}{l}0.132^{* * *} \\
(0.022)\end{array}$ \\
\hline constant & $\begin{array}{l}2.406^{* * *} \\
(0.446) \\
\end{array}$ & $\begin{array}{l}2.075^{* * *} \\
(0.509) \\
\end{array}$ & $\begin{array}{l}2.020^{* * *} \\
(0.493) \\
\end{array}$ & $\begin{array}{l}2.360^{* * *} \\
(0.348) \\
\end{array}$ & $\begin{array}{l}4.941^{* *} \\
(2.236)\end{array}$ & $\begin{array}{l}1.950^{* * *} \\
(0.379) \\
\end{array}$ \\
\hline observations & 392 & 392 & 312 & 312 & 242 & 366 \\
\hline R-squared ${ }^{\dagger}$ & 0.89 & 0.89 & 0.92 & 0.44 & 0.75 & 0.90 \\
\hline R-squared ${ }^{\ddagger}$ & 0.23 & 0.28 & 0.43 & 0.43 & 0.42 & 0.36 \\
\hline
\end{tabular}

Notes: Robust standard errors in parentheses. Stars indicate level of significance $\left(^{*}: 10 \%\right.$; ${ }^{* *}$ : $5 \%$; ${ }^{* *}: 1 \%$ ). The first measure for R-squared $\left(^{\dagger}\right)$ is given with country and time fixed effects [except for column (4) which has only time effects], the second measure $\left(^{\ddagger}\right)$ excludes country and time fixed effects. 
a non-trivial one. In contrast, the coefficients of the wage share and GDP variables are not significant in the regression of column (1), and this generally remains true when further (international) variables are added.

The regressions in columns (2) to (4) add the two main proxies for capital market integration that have been used in previous literature. Column (2) incorporates the share of commodity trade in GDP as an explanatory variable. This variable has an unexpected positive sign, but the coefficient is not statistically different from zero. Hence our regression results suggest that trade openness is not a good proxy for capital market openness. In column (3) we include instead Quinn's (1997) measure of capital controls. This measure is statistically significant, but - recalling that an increase in the index represents an opening of capital markets - the coefficient has the wrong sign. This result seemingly contradicts earlier findings by Quinn (1997) and Rodrik (1997), who both found that a liberalisation of international capital controls reduces the corporate tax rate. The apparent discrepancy is resolved by noting that our specification in column (3) uses country fixed effects. When these are eliminated, as in column (4), the sign of the capital control variable is reversed, and now matches the theoretical expectations and previous findings. Hence the conclusion is that Quinn's capital control variable is able to explain cross-country differences in the ratio of corporate to wage taxation, but it is not well suited to predict country-specific changes in this ratio over time. Proposition 1(b) is thus confirmed only from a cross-country perspective.

Column (5) incorporates the outward stock of FDI as an explanatory variable. As we have discussed above, this variable is endogenous and its effect of this variable on the mix of wage and profit taxes is theoretically ambiguous (cf. Table 2). In order to deal with the endogeneity and use this variable as a proxy for capital market integration, we instrument this variable by Quinn's capital control measure. Intuitively, this means that we focus attention on the changes in FDI stocks which were caused by the opening of capital markets, rather than tax rates. Specified in this way, a high FDI stock is correlated with a low ratio of $\tau / t$, indicating that the FDI stock is a further measure for the 'openness' of an economy. However, this negative relationship is not statistically significant. Moreover, the findings with respect to this variable are subject to the caveats about Quinn's measure, as detailed above.

Our discussion so far has shown that none of the traditional measures of 'openness' 
are a good predictor for the changes in the mix of wage and profit taxation that occur in a given country over time. Finally, column (6) employs the ratio of service to manufacturing value added as an (inverse) proxy for the share of capital located in internationally mobile firms. This variable has the expected sign, as an increase in the share of relatively immobile capital in the service sector increases the relative reliance on profit taxation. The relationship is found to be significant at the $1 \%$ level, thus confirming Proposition 1(c) of our theoretical model. Moreover, this result holds up if any of the other measures of openness are added to the regression, or if the world average tax rate is included (as reported below). At first sight the small coefficient appears to suggest that this relationship is not very important economically. The ratio of service to manufacturing value-added however increased on average by 8.3 percentage points per year, implying - other things equal - an increase in the tax ratio by one percentage point per year. ${ }^{19}$

We now include the world average tax rate as an explanatory variable. As discussed above, this implies that we cannot employ year fixed effects. To still allow for some common unexplained movement over time, we add a trend variable in these regressions. It turns out that this time trend yields results that are quite similar to those with time fixed effects. Another issue is that the world average tax rate is likely to be endogenous, if all countries set their tax rates following the model introduced above. We deal with this by calculating the average tax rate using a far larger sample of 70 countries. Nevertheless some attenuation bias may remain. The results of these regressions are given in Table 5 .

Columns (1) and (2) in Table 5 show that the average world tax rate is positively and strongly correlated with the ratio of corporate to wage taxes in the OECD countries. This confirms the theoretical prediction in Proposition 1(a). While the large coefficient may seem surprising, it should be remembered that the dependent variable is a ratio whose denominator is smaller than one. With an average wage tax rate in our sample in the range of one third, a comparable increase in corporate tax rates abroad and

\footnotetext{
${ }^{19}$ This increase of 8.3 percentage points is caused by the relatively high ratio of service to manufacturing value added (equal to 3.5, on average). This represents an increase of on average just 0.4 percentage points in the ratio of value added in services over the sum of value added in services and manufacturing.
} 
Table 5: Estimation results with world tax rate

\begin{tabular}{|c|c|c|c|c|}
\hline \multirow[b]{2}{*}{ dependent variable } & (1) & $(2)$ & $(3)$ & $(4)$ \\
\hline & \multicolumn{4}{|c|}{ corporate income /wage tax $(\tau / t)$} \\
\hline country effects & $\sqrt{ }$ & $\sqrt{ }$ & $\sqrt{ }$ & $\sqrt{ }$ \\
\hline \multirow[t]{2}{*}{ pub_cons } & & & $-4.394^{* * *}$ & $-4.325^{* * *}$ \\
\hline & & & $(1.358)$ & $(1.270)$ \\
\hline wage_share & & & $\begin{array}{l}0.584 \\
(0.716)\end{array}$ & \\
\hline GDP & & & $\begin{array}{l}0.023 \\
(0.019)\end{array}$ & $\begin{array}{l}0.044^{* * *} \\
(0.017)\end{array}$ \\
\hline service_share & & & $\begin{array}{l}0.138^{* * *} \\
(0.021)\end{array}$ & $\begin{array}{l}0.122^{* * *} \\
(0.015)\end{array}$ \\
\hline world _tax & $\begin{array}{l}4.922^{* * *} \\
(0.330)\end{array}$ & $\begin{array}{l}3.325^{* *} \\
(1.409)\end{array}$ & $\begin{array}{l}4.164^{* * *} \\
(1.456)\end{array}$ & $\begin{array}{l}3.486^{* *} \\
(1.464)\end{array}$ \\
\hline year & & $\begin{array}{l}-0.010 \\
(0.010)\end{array}$ & $\begin{array}{c}-0.017^{*} \\
(0.010)\end{array}$ & $\begin{array}{l}-0.025^{* *} \\
(0.010)\end{array}$ \\
\hline constant & $\begin{array}{l}-0.415^{* * *} \\
(0.117)\end{array}$ & $\begin{array}{l}20.031 \\
(19.470)\end{array}$ & $\begin{array}{l}34.334^{*} \\
(20.391)\end{array}$ & $\begin{array}{l}49.608^{* *} \\
(20.456)\end{array}$ \\
\hline observations & 418 & 418 & 366 & 392 \\
\hline R-squared ${ }^{\dagger}$ & 0.87 & 0.87 & 0.89 & 0.88 \\
\hline R-squared ${ }^{\ddagger}$ & 0.10 & 0.10 & 0.45 & 0.40 \\
\hline
\end{tabular}

Notes: Robust standard errors in parentheses. Stars indicate level of significance $\left({ }^{*}: 10 \%{ }^{* *}\right.$ : $5 \%$; $\left.{ }^{* *}: 1 \%\right)$. First measure for R-squared $\left(^{\dagger}\right)$ includes country fixed effects, second measure $\left({ }^{\ddagger}\right)$ excludes country fixed effects. 
domestically would thus lead to a coefficient of about 3 . The coefficient is reduced when a time trend is simultaneously introduced, but it remains significant. Column (3) adds in the variables that were discussed above. The results in this column show that both the public consumption variable and the share of services in value added remain highly significant under the changed specification. Moreover, their coefficients are almost unchanged, pointing to the robustness of our results with respect to these core explanatory variables. At the same time the coefficient of the world tax rate even increases in size when the new variables are added. Finally, column (4) shows that when the wage share variable is omitted, the absolute size of a country also turns significant at the $1 \%$ level. Hence in this final specification our empirical analysis does lend some support to the proposition that country size can be used as a proxy to measure the exposure to international capital market integration. The composition of output as a proxy for the share of multinationals also remains significant in this specification, however. In sum, the regression results in Table 5 show that the variables identified in our simple model are indeed relevant in explaining the changes in the mix of corporate and wage taxation that OECD countries have undertaken during the last two decades. The results presented in Tables 4 and 5 all report heteroskedasticity-robust standard errors. It is however likely that the disturbances are also autocorrelated. To test and allow for such autocorrelated disturbances, we use the Baltagi and Wu (1999) method for allowing for $\mathrm{AR}(1)$ autocorrelated disturbances in panel data. Table 6 reports the results for the main specifications. Overall they indicate that our findings are robust to allowing for autocorrelated disturbances, even though the relationship between the tax ratio and the preference for public goods is weakened. One difference to the results presented above is that the coefficient of the wage share variable is now significant at the 5 per cent level. The positive coefficient of this variable contradicts our theoretical prediction in Proposition 1(e). One possible explanation for this finding is that our simple political economy model leaves out some additional effects, relating to changes in the political power of labour in response to its factor share in the national economy. Finally, the results suggest that autocorrelation is likely to be present in our data, as is seen from consistently low locally best invariant test (LBI) statistics. 
Table 6: Estimation results using Baltagi and Wu (1999) method

\begin{tabular}{|c|c|c|c|c|c|}
\hline dependent variable & \multicolumn{5}{|c|}{ corporate income tax / wage tax $(\tau / t)$} \\
\hline country effects & $\sqrt{ }$ & $\sqrt{ }$ & $\sqrt{ }$ & $\sqrt{ }$ & $\sqrt{ }$ \\
\hline year effects & $\sqrt{ }$ & $\sqrt{ }$ & $\sqrt{ }$ & $\sqrt{ }$ & - \\
\hline pub_cons & $\begin{array}{l}-1.585 \\
(1.474)\end{array}$ & $\begin{array}{l}-1.362 \\
(1.489)\end{array}$ & $\begin{array}{l}-3.272^{*} \\
(1.737)\end{array}$ & $\begin{array}{c}-2.441^{*} \\
(1.449)\end{array}$ & $\begin{array}{l}-2.023 \\
(1.309)\end{array}$ \\
\hline wage_share & $\begin{array}{l}1.792^{* *} \\
(0.873)\end{array}$ & $\begin{array}{l}1.857^{* *} \\
(0.875)\end{array}$ & $\begin{array}{l}2.124^{* *} \\
(1.047)\end{array}$ & $\begin{array}{l}2.027^{* *} \\
(0.800)\end{array}$ & $\begin{array}{l}1.834^{* *} \\
(0.748)\end{array}$ \\
\hline GDP & $\begin{array}{l}0.034 \\
(0.069)\end{array}$ & $\begin{array}{l}0.047 \\
(0.070)\end{array}$ & $\begin{array}{l}0.019 \\
(0.071)\end{array}$ & $\begin{array}{l}0.058 \\
(0.067)\end{array}$ & $\begin{array}{l}0.051 \\
(0.063)\end{array}$ \\
\hline trade_share & & $\begin{array}{l}0.202 \\
(0.184)\end{array}$ & & & \\
\hline cap_controls & & & $\begin{array}{l}0.010 \\
(0.043)\end{array}$ & & \\
\hline service_share & & & & $\begin{array}{l}0.118^{* * *} \\
(0.044)\end{array}$ & $\begin{array}{l}0.101^{* *} \\
(0.040)\end{array}$ \\
\hline world_tax & & & & & $\begin{array}{l}5.316^{* * *} \\
(0.923)\end{array}$ \\
\hline constant & $\begin{array}{l}0.606^{* * *} \\
(0.057) \\
\end{array}$ & $\begin{array}{l}0.337^{* * *} \\
(0.071) \\
\end{array}$ & $\begin{array}{l}0.772^{* * *} \\
(0.101) \\
\end{array}$ & $\begin{array}{l}0.141^{* * *} \\
(0.050)\end{array}$ & $\begin{array}{c}-1.348^{* * *} \\
(0.069) \\
\end{array}$ \\
\hline observations & 373 & 373 & 296 & 348 & 348 \\
\hline LBI statistic & 0.59 & 0.37 & 0.76 & 0.51 & 0.51 \\
\hline number of cc & 19 & 19 & 16 & 18 & 18 \\
\hline
\end{tabular}

Notes: Standard errors in parentheses. Stars indicate level of significance $\left({ }^{*}: 10 \% ;{ }^{* *}: 5 \%\right.$; ${ }^{* * *}$ : $1 \%)$. 


\section{Discussion}

In this section we briefly compare our empirical results to those obtained in previous work on the subject. We confine our comparison to the studies that include estimates with fixed country effects; these are Bretschger and Hettich (2002), Slemrod (2004) and Winner (2005). ${ }^{20}$ We have already argued above that using an index of capital controls, as developed by Quinn (1997), allows us to explain cross-country differences in the ratio of corporate to wage taxation, but it is not well suited to predict country-specific changes in this ratio over time [cf. columns (2) and (4) of Table 4]. A similar result is obtained in the analysis of Bretschger and Hettich (2002, Table 2), where the capital controls variable loses its significance when country fixed effects are incorporated. There are two possible reasons for these results. First, the index has remained virtually constant over the last 10 years, and is thus unable to explain any changes in the ratio of wage and capital taxes that have occurred during this period. Moreover the index of capital controls is a discrete, qualitative measure that does not change smoothly and may therefore not provide a good description of gradual changes in openness over time.

Similar comments apply when capital market integration is proxied by the share of commodity trade in GDP. Both Bretschger and Hettich (2002, Table 2) and Slemrod (2004, Table 2) find that this trade-related openness measures is statistically significant in a cross-country analysis without fixed country effects, but insignificant in the presence of country dummies. ${ }^{21}$ The latter result corresponds with the findings of our analysis, as reported in column (2) of Table 4. Hence, the overall conclusion is that a trade-based measure is also not able to explain the adjustment in the factor tax mix that has occurred in OECD countries during the last two decades.

Instead, Winner (2005) uses savings-investment correlations as a proxy for capital market openness. His analysis yields a robust negative relationship between this measure of openness and the ratio of capital to labour taxation, even when country fixed effects are added. ${ }^{22}$ Winner bases his empirical analysis on average tax ratios, calculated from

\footnotetext{
${ }^{20}$ Note that Slemrod's (2004) analysis focuses only on the determinants of corporate taxation.

${ }^{21}$ We report here the results that Bretschger and Hettich (2002) find for the conventional traderelated measure of openness (labelled openness1 in their analysis).

${ }^{22}$ Winner's analysis also includes a dynamic specification. The results of this model suggest that
} 
collected tax revenue. Hence, in comparison to our analysis, both the tax measures and the proxies for capital market integration differ. Savings-investment correlations (as a proxy for overall capital mobility) and the sectoral composition of output (as a proxy for the mobility of firms) thus seem to be complementary measures that are both able to account for country-specific changes in the factor tax mix over time.

Turning to other explanatory variables, country size (or GDP) is included in all the empirical works mentioned above. This variable generally has a positive effect on the ratio of capital to labour taxation (or on the isolated capital tax rate), but the effect is significant only for a subset of the estimated model specifications. These results correspond closely to the findings of our analysis.

A core variable in our analysis is the share of government consumption in GDP. This variable is not included in the analyses of Bretschger and Hettich (2002) and Winner (2005). It is incorporated, however, by Slemrod (2004, Table 2), who finds no significant effect of an increase in government consumption on the statutory corporate tax rate. This corresponds to the ambiguous sign that the variable $\gamma$ has on the corporate tax rate in our analysis [cf. eq. (12)] and implies that an increase in government consumption will be financed largely by an increase in wage taxation. Hence Slemrod's finding is consistent with our result that an increase in government consumption expenditure lowers the ratio of capital to wage taxation (Tables 4 and 5).

To summarise, there is a considerable consensus in the empirical literature that capital market integration does indeed change the factor tax mix, in the direction of a reduced reliance on capital taxes. It is essential, however, to clearly distinguish between a pooled analysis, where cross-country and time-series effects are simultaneously included, and an analysis that focuses on explaining the changes over time within a given country using country fixed effects. Following the latter approach unveils the weaknesses of some of the conventional measures of capital market integration, which do not contribute to explaining the changes in the structure of direct taxation which have occurred in OECD member countries. Additional variables that may account for these changes, as derived here from a theoretical model, have so far received only scant attention in the empirical literature. But where such evidence exists, it is compatible with our results.

the downward effect of capital mobility on the capital tax burden has intensified since the mid-1980s. 


\section{Concluding remarks}

In this paper, we have set up a simple model that allows us to derive rigorously a number of testable hypotheses relating the mix of corporate taxation to wage taxation to a number of country-specific variables. In addition to restating some well-known results from the existing literature on capital tax competition, we have also emphasised two relationships that have received little attention so far. First, we have shown that increasing the share of multinational firms' income in an economy will, other things being equal, lower the corporate income tax. Second, an increase in government consumption will increase this country's relative reliance on wage taxes, at least for a wide range of 'plausible' parameter values.

In a second step, we have tested the theoretical predictions using data from 23 OECD countries for the period 1980-2001. Overall, the empirical results have confirmed the theoretical results from our simple model. In particular, the share of government consumption turned out to be one core determinant of the factor tax mix in OECD countries. Moreover, proxying the share of multinationals in the economy by a simple ratio of value added in the service and manufacturing sectors proved to be a powerful explanatory variable that outperformed traditional openness measures like the share of international commodity trade or an index of international capital controls.

The limitations of our analysis should also be stressed, however. From a theoretical perspective, we have postulated a simple median voter model where changes in the relative factor shares of labour and capital do not affect the political equilibrium. The prediction from this model that an increase in the share of wage income should reduce the ratio of capital taxation to labour taxation are not confirmed by our empirical analysis. This suggests that a more elaborated political economy model is needed. In the empirical part of the analysis, it would be desirable to have a more direct summary measure of the value added by mobile, multinational firms in a given country. We suspect that such a measure would be a highly suitable proxy for the country-specific exposure to the forces of corporate tax competition. 
Table A.1: Data sources and methods

\begin{tabular}{|c|c|c|}
\hline Variable & Source & Definition and methodology \\
\hline $\begin{array}{l}\text { Corporate } \\
\text { income tax } \\
\text { rate }\end{array}$ & $\begin{array}{l}\text { IFS data } \\
\text { and own } \\
\text { calculations }\end{array}$ & $\begin{array}{l}\text { Statutory tax plus typical local taxes and other } \\
\text { surtaxes. Where multiple rates are available, the } \\
\text { manufacturing rate is chosen. }\end{array}$ \\
\hline $\begin{array}{l}\text { Wage tax } \\
\text { rate }\end{array}$ & $\begin{array}{l}\text { OECD Taxing } \\
\text { Wages }\end{array}$ & $\begin{array}{l}\text { Average tax wedge of manufacturing worker on } \\
\text { average income. This includes personal income taxes, } \\
\text { employer and employee social security contributions } \\
\text { and payroll taxes. We have taken the average of the } \\
\text { rate for married and single workers. Before 1993, this } \\
\text { is reported biannually, and we use linear interpolation. }\end{array}$ \\
\hline pub_cons & $\begin{array}{l}\text { OECD National } \\
\text { Accounts }\end{array}$ & Public consumption expenditure divided by GDP \\
\hline wage_share & $\begin{array}{l}\text { OECD Economic } \\
\text { Outlook }\end{array}$ & Wages and salaries divided by GDP \\
\hline GDP & $\begin{array}{l}\text { OECD National } \\
\text { Accounts }\end{array}$ & $\begin{array}{l}\text { GDP in trillion US } \$ \text {, converted at purchasing } \\
\text { power parity exchange rates }\end{array}$ \\
\hline trade_share & $\begin{array}{l}\text { OECD National } \\
\text { Accounts }\end{array}$ & The sum of exports and imports divided by GDP \\
\hline cap_controls & $\begin{array}{l}\text { Comparative } \\
\text { Welfare States } \\
\text { Data Set* }\end{array}$ & $\begin{array}{l}\text { Index ranging from } 0 \text { (closed capital markets) to } 4 \\
\text { (open capital markets) }\end{array}$ \\
\hline service_share & $\begin{array}{l}\text { OECD STAN } \\
\text { (Structural Ana- } \\
\text { lysis Database) }\end{array}$ & $\begin{array}{l}\text { Value added in the service sector divided by value } \\
\text { added in the manufacturing sector }\end{array}$ \\
\hline FDI_stock & $\begin{array}{l}\text { OECD Inter- } \\
\text { national Direct } \\
\text { Investment }\end{array}$ & Stock of foreign direct investment divided by GDP \\
\hline world_tax & $\begin{array}{l}\text { World Tax Data Base, } \\
\text { University of Michi- } \\
\text { gan Business School, } \\
\text { own calculations }\end{array}$ & $\begin{array}{l}\text { Average statutory corporate income tax rate, not } \\
\text { including local taxes, of } 70 \text { countries for which } \\
\text { continuous data are available from } 1980 \text { to } 2001 \text {. }\end{array}$ \\
\hline
\end{tabular}

Notes: - IFS data available from: www.ifs.org.uk/publications.php?publication_id=3210

- All OECD data available from: new.sourceoecd.org

- World tax data base available from: www.bus.umich.edu/otpr/otpr/introduction.htm

*Full source: E. Huber, Ch. Ragin, J. D. Stephens, D. Brady, and J. Beckfield, Comparative

Welfare States Data Set, mimeo 2004. Original source of the measure: Quinn (1997). 
Table A.2: Multinational firms in services and manufacturing (1998)

\begin{tabular}{|l||c|c|c||c|c|c|}
\hline \multicolumn{1}{|c||}{} & \multicolumn{3}{c||}{ inward FDI $^{a}$} & \multicolumn{3}{c|}{ outward FDI $^{b}$} \\
\hline & services & manufac- & ratio & services & manufac- & ratio \\
& $(1)$ & turing $(2)$ & $(1):(2)$ & $(1)$ & turing $(2)$ & $(1):(2)$ \\
\hline Austria & 0.14 & 0.26 & 0.54 & 0.04 & 0.07 & 0.57 \\
Belgium & 0.26 & 0.47 & 0.55 & 0.08 & 0.08 & 1.00 \\
Finland & 0.15 & 0.14 & 1.07 & 0.20 & 0.43 & 0.47 \\
France & & & & 0.08 & 0.16 & 0.50 \\
Japan & 0.01 & 0.02 & 0.5 & 0.07 & 0.09 & 0.78 \\
Luxembourg & 0.15 & 0.52 & 0.29 & & & \\
Netherlands & 0.16 & 0.30 & 0.53 & & & \\
Norway & 0.20 & 0.17 & 1.18 & & & \\
Portugal & & & & 0.02 & 0.03 & 0.67 \\
Sweden & 0.19 & 0.19 & 1.00 & & & \\
United Kingdom & 0.17 & 0.31 & 0.55 & & & \\
United States & 0.08 & 0.17 & 0.47 & & & \\
\hline \hline average & 0.19 & 0.26 & 0.67 & 0.05 & 0.09 & 0.67 \\
\hline
\end{tabular}

${ }^{a}$ Foreign controlled turnover as a share of total services and manufacturing turnover.

${ }^{b}$ Turnover of affiliates of national firms located abroad compared with total national turnover.

${ }^{c}$ unweighted.

Source: OECD (2001): Measuring globalisation. The role of multinationals in OECD Economies, Volume II: Services, Figures 4 and 7. 
Figure A.1: Country-specific ratios of corporate taxes to wage taxes
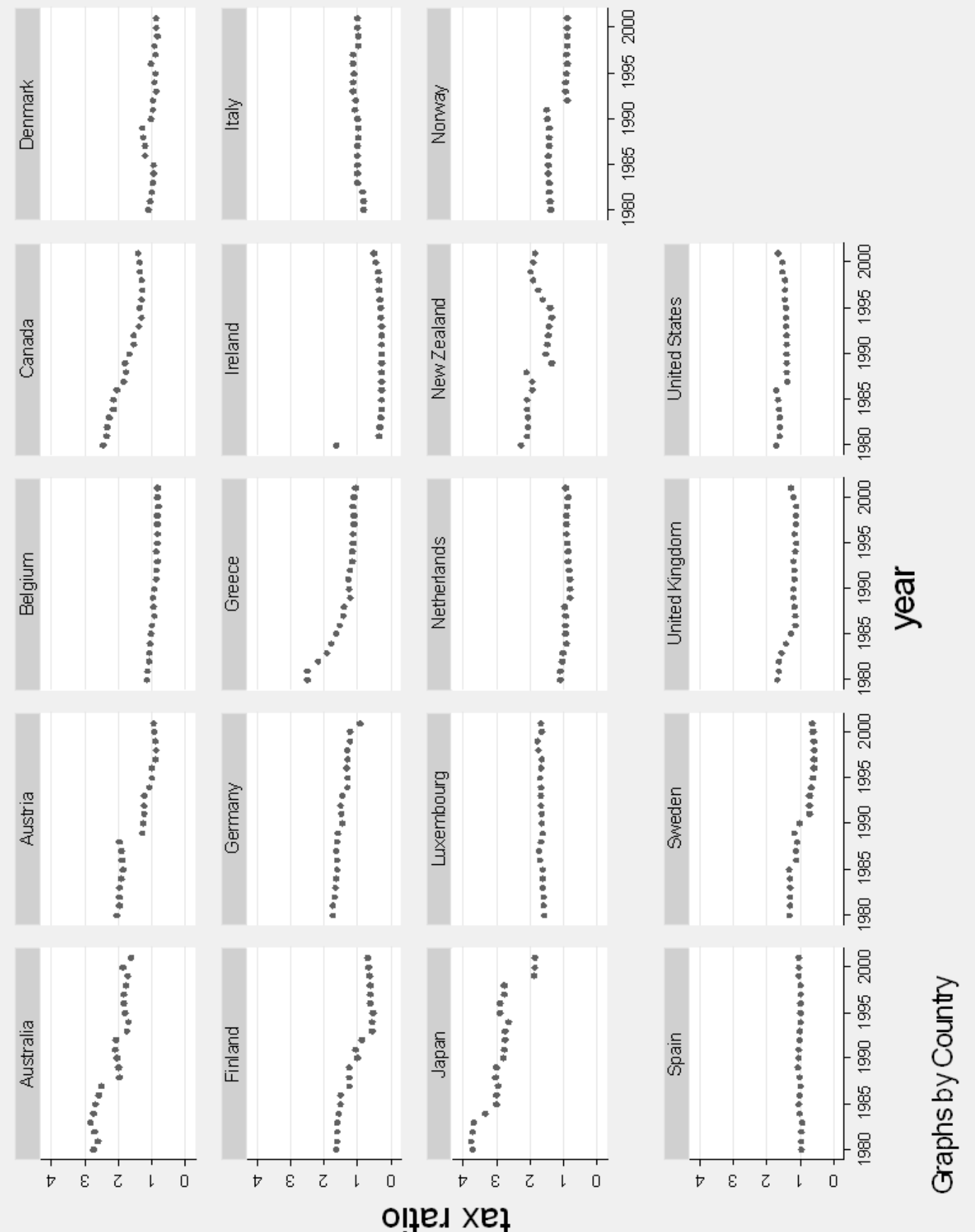


\section{References}

Baltagi, B.H. and P.X. Wu (1999), Unequally spaced panel data regressions with AR(1) disturbances. Econometric Theory 15, 814-823.

Besley, T., R. Griffith and A. Klemm (2001), Empirical evidence on fiscal interdependence in OECD countries. Mimeo.

Bretschger, L. and F. Hettich (2002), Globalisation, capital mobility and tax competition: Theory and evidence for OECD countries. European Journal of Political Economy 18, 695-716.

Brueckner, J. (2003), Strategic interaction among governments: An overview of empirical studies. International Regional Science Review 26, 175-188.

Bucovetsky, S. (1991), Asymmetric tax competition. Journal of Urban Economics 30, 167-181.

Bucovetsky, S. and A. Haufler (2005), Tax competition when firms choose their organizational form: Should tax loopholes for multinationals be closed? CESifo Working Paper 1625. Munich.

Bucovetsky, S. and J.D. Wilson (1991), Tax competition with two tax instruments. Regional Science and Urban Economics 21, 333-350.

Devereux, M.P. and R. Griffith (2003), Evaluating tax policy for location decisions. International Tax and Public Finance 10, 107-126.

Devereux, M. P., R. Griffith, and A. Klemm (2002), Corporate income tax reforms and international tax competition. Economic Policy 35, 451-495.

Devereux, M.P. and A. Klemm (2004), Measuring taxes on income from capital: evidence from the UK. In: P.B. Sorensen (ed.), Measuring the Tax Burden on Capital and Labor, MIT Press, Cambridge, 73-98.

Devereux, M.P., B. Lockwood and M. Redoano (2002), Do countries compete over corporate tax rates? CEPR Discussion Paper 3400, London. 
European Commission (1997), Towards tax co-ordination in the European Union: a package to tackle harmful tax competition. Document COM (97) 495, Brussels.

European Commission (2001), Towards an internal market without tax obstacles. A strategy for providing companies with a consolidated corporate tax base for their EU-wide activities. Document COM (2001) 582, Brussels.

Eurostat (1998), Structures of the taxation system in the European Union 1970-1996. Luxembourg.

Eurostat (2005), Structures of the taxation system in the European Union - Data 1995-2003. Luxembourg.

Fuest, C. and B. Huber (2000), Why do countries subsidise investment and not employment?, Journal of Public Economics 78, 171-192.

Ghosh, A. and H. Wolf (1997), Geographical and sectoral shocks in the US business cycle. NBER Working Paper 6180.

Grubert, H., and J. Mutti, 2000, Do taxes influence where U.S. corporations invest? National Tax Journal 53, 825-839.

Haufler, A. and I. Wooton (1999), Country size and tax competition for foreign direct investment. Journal of Public Economics 71, 121-139.

Janeba, E. and W. Peters (1999), Tax evasion, tax competition and the gains from nondiscrimination: The case of interest taxation in Europe. The Economic Journal 109, 93-101.

Jimeno, J.F. (1992), The relative importance of aggregate and sector-specific shocks at explaining aggregate and sectoral fluctuations. Economics Letters 39, 381-385.

Keen, M. (2001), Preferential regimes can make tax competition less harmful. National Tax Journal 54, 757-762.

Kind, H.J., K.H. Midelfart and G. Schjelderup (2005), Corporate tax systems, multinational enterprises, and economic integration. Journal of International Economics, 65, 507-521. 
Markusen, J. (2002), Multinational firms and the theory of international trade. MIT Press, Cambridge.

Mintz, J. and M. Smart (2004), Income shifting, investment, and tax competition: theory and evidence from provincial taxation in Canada. Journal of Public Economics 88, 1149-1168.

OECD (2001), Measuring globalisation. The role of multinationals in OECD Economies, Volume II: Services. Paris.

OECD (2005), Taxing wages. www.new.sourceoecd.org.

Persson, T. and G. Tabellini (1992), The politics of 1992: Fiscal policy and European integration. Review of Economic Studies 59, 689-701.

Quinn, D. (1997), The correlates of change in international financial regulation. American Political Science Review 91, 531-551.

Rodrik, D. (1997), Has globalisation gone too far? Institute for International Economics, Washington, D.C.

Slemrod, J. (2004), Are corporate tax rates, or countries, converging?, Journal of Public Economics 88, 1169-1186.

Sørensen, P.B. (2000), The case for international tax coordination reconsidered. Economic Policy 31, 429-472.

Swank, D. and S. Steinmo (2002), The new political economy of taxation in advanced capitalist democracies. American Journal of Political Science 46, 642-655.

Wilson, J.D. (1991), Tax competition with interregional differences in factor endowments. Regional Science and Urban Economics 21, 423-451.

Wilson, J.D. (1999), Theories of tax competition. National Tax Journal 52, 269-304.

Winner, H. (2005), Has tax competition emerged in OECD countries? Evidence from panel data. International Tax and Public Finance 12, 667-687. 